\title{
Factors Within University-Based Teacher Education Relating to Preservice Teachers' Professional Vision
}

Citation for published version (APA):

Stuermer, K., Koenings, K. D., \& Seidel, T. (2015). Factors Within University-Based Teacher Education Relating to Preservice Teachers' Professional Vision. Vocations and Learning, 8(1), 35-54.

https://doi.org/10.1007/s12186-014-9122-z

Document status and date:

Published: 01/04/2015

DOI:

10.1007/s12186-014-9122-z

Document Version:

Publisher's PDF, also known as Version of record

Document license:

Taverne

Please check the document version of this publication:

- A submitted manuscript is the version of the article upon submission and before peer-review. There can be important differences between the submitted version and the official published version of record.

People interested in the research are advised to contact the author for the final version of the publication, or visit the DOI to the publisher's website.

- The final author version and the galley proof are versions of the publication after peer review.

- The final published version features the final layout of the paper including the volume, issue and page numbers.

Link to publication

\footnotetext{
General rights rights.

- You may freely distribute the URL identifying the publication in the public portal. please follow below link for the End User Agreement:

www.umlib.nl/taverne-license

Take down policy

If you believe that this document breaches copyright please contact us at:

repository@maastrichtuniversity.nl

providing details and we will investigate your claim.
}

Copyright and moral rights for the publications made accessible in the public portal are retained by the authors and/or other copyright owners and it is a condition of accessing publications that users recognise and abide by the legal requirements associated with these

- Users may download and print one copy of any publication from the public portal for the purpose of private study or research.

- You may not further distribute the material or use it for any profit-making activity or commercial gain

If the publication is distributed under the terms of Article $25 \mathrm{fa}$ of the Dutch Copyright Act, indicated by the "Taverne" license above, 


\title{
Factors Within University-Based Teacher Education Relating to Preservice Teachers' Professional Vision
}

\author{
Kathleen Stürmer • Karen D. Könings • Tina Seidel
}

Received: 24 April 2014 / Accepted: 29 September 2014 /

Published online: 8 October 2014

(C) Springer Science+Business Media Dordrecht 2014

\begin{abstract}
Preservice teachers' professional vision is an important indicator of their initial acquisition of integrated knowledge structures within university-based teacher education. To date, empirical research investigating which factors contribute to explaining preservice teachers' professional vision is scarce. This study aims to determine which factors are related to preservice teachers' incipient professional vision and may constitute necessary conditions for development processes. The participants were 55 preservice teachers who completed a questionnaire investigating their individual characteristics and opportunities used for learning and a video-based tool assessing their professional vision regarding generic pedagogical knowledge of teaching and learning. We conducted multiple regression analyses to identify relevant factors. The results showed that the number of attended courses on teaching and learning and the level of interest in the content are closely related to higher levels of professional vision. No relation was found with practical experience. It is concluded that professional vision is related to conditions of content-specific knowledge acquisition, as provided in formal teacher education programs.
\end{abstract}

Keywords Teacher education · Teacher expertise $\cdot$ Professional vision · Formal and informal learning

Teachers' professional knowledge is seen as essential for teaching quality in classrooms, and thus, for students achievement (Cochran-Smith and Zeichner 2005; Darling-Hammond 2010; Darling-Hammond and Bransford 2005). Current research shows that the development of this knowledge is impacted by initial teacher education (i.e., Baumert et al. 2010). As the first step of two consecutive educational phases, initial teacher education in most European countries is affiliated with universities,

K. Stürmer $(\bowtie) \cdot$ T. Seidel

TUM School of Education, Technische Universität München, Schellingstr. 33, 80799 Munich, Germany

e-mail: kathleen.stuermer@tum.de

K. D. Könings

School of Health Professions Education, Department of Educational Development \& Research, Maastricht University, Maastricht, The Netherlands 
followed by a professional learning phase in schools (Bauer and Prenzel 2012). In providing knowledge about what constitutes effective teaching and learning (CochranSmith 2003; Darling-Hammond 2006; Darling-Hammond and Bransford 2005; Noell and Burns 2006), universities aim to support professional knowledge acquisition related to instructional practice (Brouwer 2010; Darling-Hammond and Bransford 2005; Grossman et al. 2009). To enable preservice teachers to apply what they have learned to practice, the educational programs are required to foster the development of well-defined and differentiated knowledge connected to multiple instructional contexts (Borko 2004; Putnam and Borko 2000). Thereby, the quality of university-based teacher education is reflected in the extent to which preservice teachers acquire integrated knowledge structures (Seidel et al. 2013).

For evaluating the quality of initial teacher education at universities, it is important to identify factors that contribute to achieving academic outcomes (Fenollar et al. 2007; Ruban and McCoach 2005), such as an integrated knowledge base with good transfer to practice. These factors are indicators in studying preservice teachers' learning processes and help improve curricular designs regarding the ongoing efforts in teacher education reform (Bauer and Prenzel 2012; Musso et al. 2013). Research investigating factors that have a predictive impact on learning processes focuses on preservice teachers' individual characteristics (Blömeke et al. 2012; Kunina-Habenicht et al. 2013) and the meaning of formal and informal opportunities to learn (OTL) as sources for acquiring knowledge (Grossman 1990). Despite a rich body of research, the significance of the findings remains unclear regarding measures of preservice teachers' academic outcomes (Wiens et al. 2013). Most instruments capture students' subjective judgments of their abilities or use rather distal indicators, such as courses taken, certificates, or degrees. Although grade point average (GPA), for example, has been proven in general to be a predictor of job success (Strenze 2007), the validity of such measures for experienced on-job performance, such as effective teaching, has been criticized (Ericsson et al. 1993; Voss et al. 2011; Wayne and Youngs 2003). Researchers have recently answered this criticism with the development and use of standardized knowledge tests (Baumert et al. 2010; Hill et al. 2005; Kleickmann et al. 2012; Voss et al. 2011) based on Shulman's proposed structure of teacher knowledge in content knowledge, pedagogical content knowledge, and generic pedagogical knowledge (Shulman 1987). Although these studies show the relation between teacher knowledge and student achievement (i.e., Loewenberg Ball and Cohen 1999), they do not assess the application of knowledge in a practice context. For defining effective teacher education through the support of developing integrated and flexible knowledge structures, indicators are essential, as are valid and reliable measurements in terms of real instructional practice (Grossman et al. 2009; Seidel 2012).

A promising indicator of integrated teacher knowledge is professional vision (Goodwin 1994), which describes the ability to draw on conceptual knowledge about teaching and learning to notice and interpret significant features of classroom situations (van Es and Sherin 2002). In the last few years, this concept has become more important for describing initial knowledge acquisition within university-based teacher education (Santagata and Guarino 2010; Star and Strickland 2008; Stürmer, Könings, \& Seidel 2012; Stürmer et al. 2013; Wiens et al. 2013). Furthermore, original standardized instruments have been developed to assess professional vision within teacher education that use a formative approach (Seidel and Stürmer 2014). 
The current study aims to advance the scientific understanding of factors that contribute to explaining teachers' professional knowledge acquisition. In a German university, we investigate which factors are related to preservice teachers' professional vision as an indicator of their development of integrated knowledge structures. We focus on the relation between preservice teachers' incipient professional vision and influencing factors at the beginning of their educational program. Against the background that knowledge acquisition begins to develop even before preservice teachers enter teacher education (Lortie 1975), the early assessment point has the advantage that preservice teachers commonly start to acquire formal knowledge about effective teaching and learning. Factors that explain differences in preservice teachers' initial professional vision might constitute important opportunities for the development process. This allows us to critically discuss how initial university teacher education may contribute to an effective outcome for instructional practice.

\section{Professional Vision as an Indicator of Integrated Knowledge Acquisition}

Professional vision highlights the key relevance of knowledge-based perceptual processes for teacher expertise (Goodwin 1994; Sherin 2002). This concept describes the ability to notice and interpret relevant features of classroom events for student learning (Sherin 2007; van Es and Sherin 2002). Thus, professional vision is a prerequisite for effective teaching practice (Grossman et al. 2009; Sherin 2001). Professional vision requires conceptual knowledge about effective teaching and learning (Borko 2004; Palmeri et al. 2004; Stürmer et al. 2013) and the ability to apply this knowledge to the situation observed (Berliner 1991; Sherin and van Es 2009). Especially regarding preservice teachers' learning, the concept constitutes a promising approach for capturing knowledge acquisition relevant for future teaching practice (Wiens et al. 2013). Professional vision entails two interconnected knowledge-based subcomponents: (a) noticing, which describes the ability to direct attention to relevant classroom situations, and (b) knowledge-based reasoning, which indicates how events in the classroom are interpreted (van Es and Sherin 2008).

Noticing involves identifying classroom situations and events that, from a professional perspective, are decisive for effective instructional practice (Seidel and Stürmer 2014). Preservice teachers need to develop the ability to recognize components of effective teaching that support students' learning processes. In instruction, numerous teaching and learning acts occur. Some are particularly important for student learning; others are not. In this vein, the situations and events preservice teachers direct their attention to, while observing a classroom situation, serve as the first indicator of underlying knowledge (Sherin et al. 2011). When it comes to defining relevant situations for teaching and learning, different knowledge foci that provide a frame for capturing preservice teachers' knowledge application (van Es and Sherin 2008) can be applied. In our research, we focus on knowledge about principles of teaching and learning (Grossman and McDonald 2008) as an aspect of generic pedagogical knowledge (Shulman 1987), which represents a basic component of initial university-based teacher education (Hammerness et al. 2002; Voss et al. 2011). Generic pedagogical knowledge is essential for creating learning environments across a wide variety of subjects (Voss et al. 2011) in a domain-general manner (Blomberg et al. 2011). 
Teaching effectiveness research is based on knowledge about teaching and learning as an element of generic pedagogical knowledge. In this research, many teaching components have been repeatedly shown to be relevant for students' learning (Seidel and Shavelson 2007). In our research, we focus on three components: goal clarity and orientation, teacher support and guidance, and learning climate (Seidel and Stürmer 2014). Learning climate is an indicator of the motivational-affective classroom context, goal clarity and orientation indicate successful preparation for learning, and teacher support is a guiding process involved in the execution of learning activities. These three components have been repeatedly identified as relevant for student learning (Fraser et al. 1987; Hattie 2009; Seidel and Shavelson 2007). The component goal clarity and orientation (i.e., clarifying teaching and learning goals, structuring the lesson) is particularly relevant to the cognitive and motivational aspects of student learning since students should activate their knowledge and be motivated to learn. Teacher support and guidance positively affects student learning, particularly in terms of motivationalaffective aspects. Teachers' questions, as well as reactions to student responses in the form of feedback, are the core elements of research in this area. The learning climate in a classroom is particularly relevant for student learning since the climate provides an important motivational and affective background in which learning takes place.

The second subcomponent of professional vision describes teachers' reasoning about classroom events. This subcomponent captures the ability to process and interpret the situations noticed, based on knowledge about teaching and learning (Borko 2004; Sherin 2007; van Es and Sherin 2002). The ability to take a reasoned approach to events noticed in the classroom provides insights into the quality of the preservice teachers' mental representations of knowledge and the application of those representations to instructional practice (Borko 2004; Borko et al. 2008). When it comes to conceptualizing teachers' reasoning, researchers distinguish qualitatively different aspects (Berliner 2001; Borko and Livingston 1989; van Es and Sherin 2008), which we refer to as: (a) description, (b) explanation, and (c) prediction (Seidel and Stürmer 2014). Description reflects the ability to identify and differentiate between relevant events without making any additional judgments. Explanation refers to the ability to use what one knows to reason about a situation. This means linking classroom events to professional knowledge and classifying situations according to the teaching components involved. Prediction refers to the ability to predict the consequences of observed events in terms of student learning. It draws on broader knowledge about teaching and student learning as well as application to instructional practice.

Since knowledge-based reasoning is an indicator of the quality of knowledge representation, in the current study we focus on assessing preservice teachers' knowledge-based reasoning ability regarding noticed teaching and learning components (goal clarity, teacher support, and learning climate). According to expertise research, this ability can be learned (Berliner et al. 1988). It has been shown that a distinct professional vision is primarily a characteristic of experienced teachers (Berliner 1991). In regard to engaging in knowledge-based reasoning, there are systematic differences in the abilities of experienced teachers and preservice teachers (Carter et al. 1987; Putnam and Borko 2000). Preservice teachers often describe classroom situations in limited and "naïve" terms and tend to overgeneralize situations (Berliner 1991), whereas experienced teachers identify critical classroom situations, explain the effects of critical classroom situations based on their knowledge, and predict 
consequences of relevant classroom situations for student learning (Seidel and Prenzel 2007). Even during the early stage of university-based education, the three aspects of knowledge-based reasoning can be empirically differentiated in preservice teachers' ability to interpret classroom situations (Seidel and Stürmer 2014). Furthermore, preservice teachers seem to start developing an understanding of the components of effective instruction and integrating this knowledge during the course of their training (Hammerness et al. 2002; Stürmer et al. 2012, 2013). However, to date no research exists that investigates the factors that contribute to explaining the differences in preservice teachers' professional vision and thus might have a predictive impact on the development processes.

\section{Factors Contributing to the Explanation of Integrated Knowledge Acquisition}

In higher education, identifying the factors that contribute to explaining knowledge acquisition is important (Fenollar et al. 2007; Ruban and McCoach 2005). Two strands of research investigate factors that have a predictive impact on preservice teachers' learning. The first strand points out the influence of preservice teachers' individual characteristics on the acquisition of knowledge (Blömeke et al. 2012; KuninaHabenicht et al. 2013). The second strand focuses on the meaning of formal and informal opportunities to learn (OTL) as sources for acquiring knowledge (Grossman 1990). In the following, we present results for both strands and discuss the findings in light of the meaning for preservice teachers' initial professional vision.

Individual Characteristics Individual characteristics determine in what way students use learning opportunities and to what extent professional knowledge acquisition takes place (Kunina-Habenicht et al. 2013). The meaning of cognitive abilities and motivation has been pointed out repeatedly (Blömeke et al. 2012; Ericsson et al. 1993). In this vein, high school grade point average (GPA) and interest in the topic are seen as important indicators.

High School GPA As a distal parameter for cognitive abilities, students' GPA illustrates the previous level of individual achievement and quality of learning experiences. Studies in higher education have consistently shown the predictive impact of high school GPA for academic achievement (e.g., Richardson et al. 2012) and professional development (Willingham et al. 1990). In terms of initial teacher education, the initial findings indicated a relation between preservice teachers' GPA and their pedagogical content knowledge (Blömeke et al. 2008) as well as their generic pedagogical knowledge (Kunina-Habenicht et al. 2013). However, the studies used either tests that capture conceptual knowledge or the study's GPA. When it comes to knowledge application in terms of instructional practice, expertise research indicates a poorly predictive value for experienced on-job performance (Ericsson et al. 1993; Hulin et al. 1990).

Interest Learning outcomes are often positively related to motivational factors (Bennware and Deci 1984; Singh et al. 2002). The mediating and direct influence on students' learning processes has been shown in several studies in higher education (i.e., Fenollar et al. 2007; Robbins et al. 2004). A central motivational factor is student 
interest (Dewey 1913). Interest-based learning is related to knowledge acquisition since interest contributes to deep-level information processing with stronger elaborations and connections to prior knowledge (Wigfield and Cambria 2010) and produces long-term engagement (Eccles 1984). Furthermore, interest influences a person's attention, goals, and level of learning (i.e., Hidi and Harackiewicz 2000) and is characterized by an interplay between affective and cognitive components (Hidi and Renninger 2006; Sansone and Thoman 2005). The two types of interest - situational interest elicited by the context and individual interest - are related to students' achievement in the context of higher education (Elliot and Murayama 2008; Harackiewicz et al. 2008; Wigfield and Cambria 2010). Since we focus on factors that may constitute a capacity for acquiring integrated knowledge during the course of professional development, we take preservice teachers' individual interest into account. In contrast to situational interest, individual interest is characterized as a relatively lasting willingness to actively engage with the learning content because of a personal connection to the subject (Hidi and Renninger 2006).

Opportunities to Learn (OTL) The second important approach that contributes to understanding preservice teachers' learning processes points out the different sources for knowledge acquisition (Grossman 1990; Munby et al. 2001; Schön 1987; Sternberg and Grigorenko 2003).

Formal Learning Opportunities Formal OTL, which usually lead to qualifying for the teacher profession, are organized and structured by initial teacher education programs at universities (Bauer, and Prenzel 2012; Kleickmann et al. 2012). They summarize the content of learning objectives for an effective teaching practice as curriculum, requirements, and courses and thus offer holistic OTL for preservice teachers (Blömeke et al. 2012). Studies that investigate how university-based teacher education affects knowledge acquisition are still limited (Cochran-Smith and Zeichner 2005). Especially regarding generic pedagogical knowledge acquisition, the impact has been criticized (Feiman-Nemser 1990; Wubbels et al. 1992). However, researchers have argued that organizing time, content, and courses in the programs play a central role in knowledge acquisition (Cochran-Smith and Fries 2005; Cochran-Smith and Zeichner 2005; Floden and Meiketti 2005). Accordingly, recent studies seem to support the assumption that university-based teacher education has a general impact on the continuous acquisition of conceptual knowledge in content and pedagogical content knowledge (Kleickmann et al. 2012) as well as generic pedagogical knowledge (Kennedy et al. 2008; KuninaHabenicht et al. 2013). Regarding integrated knowledge acquisition, one of our earlier studies has shown that preservice teachers who took courses in the principles of teaching and learning within university-based teacher education positively developed their professional vision (Stürmer et al. 2013).

Informal Learning Opportunities Informal OTL describe knowledge acquisition outside educational institutions (Eraut 2004). They are usually highly contextualized and often referred to as learning by experience (Grossman et al. 2009; Tynjälä 2008). In contrast to the diverse criticism of the impact of university-based teacher education, informal OTL through practical experience in teaching are essential for developing integrative knowledge structures (Berliner et al. 1988; Darling-Hammond and 
Bransford 2005; Grossman 1990; Putnam and Borko 2000). Well-defined knowledge structures develop only when applied in practice through contextualized generalization over teaching careers (Berliner et al. 1988; Darling-Hammond and Bransford 2005). This assumption rises from expertise research showing that on-job performance experience goes along with continued reflected learning in this context (Ericsson et al. 1993). Therefore, different forms of internships and praxis elements have been implemented in initial, university-based teacher education programs (Brouwer and Korthagen 2005; Darling-Hammond 2010) to support knowledge integration at an early stage. Often, practical experience is required before students enter the teacher education program. However, empirical studies investigating the general impact of practical experiences in teaching on preservice teachers' initial knowledge acquisition are still rare. Few studies indicate the positive effects of practical experiences on preservice teachers' self-efficacy and self-assessed teaching skills (Gröschner et al. 2013). An increase in preservice teachers' integrated knowledge was shown for practical teaching experiences that were guided through university-based courses (Stürmer et al. 2013).

\section{Research Questions}

To advance the scientific understanding of preservice teachers' initial acquisition of integrated knowledge structures and influences on the development process, we investigated which factors were associated with their professional vision at the beginning of their teacher education. We addressed the following research question: How do individual characteristics and OTL relate to preservice teachers' initial professional vision abilities, and which of these factors are most important in influencing preservice teachers' initial professional vision abilities and its subdimensions of description, explanation, and prediction?

\section{Method}

\section{Study Site}

Data collection was embedded in a compulsory introductory lecture on principles of teaching and learning in the context of a German initial teacher education program for training preservice teachers to teach at secondary school. In the program, as in most European countries, preservice teachers were educated in generic pedagogical knowledge, pedagogical content knowledge, and content knowledge referring to the subjects they are going to teach (Bauer, and Prenzel 2012). With regard to generic pedagogical knowledge, they have to take a foundational lecture on the principles of teaching and learning in the first three semesters of their educational program (OECD 2005). This lecture is seen as a curricular starting point and gives an overview of the general concepts and theories of learning and how teaching influences it. Because all students have to take this lecture in the first semesters of their educational program, the lecture sample represents the full student population. Students in the lecture are at different 
stages in their professional development, which makes them an interesting sample to study. At the same time, it is possible to investigate differences in the use of formal and informal OTL as students can take additional courses in generic pedagogical principles of teaching and learning as an elective, and they are required to gather practical experiences in teaching within the first three semesters.

\section{Participants}

All preservice teachers $(N=443)$ of the lecture voluntarily filled out a questionnaire that captured their individual characteristics and the number of formal and informal OTL. Additionally, preservice teachers were invited to work with an online instrument that measured their professional vision. Fifty-five of them filled out the instrument $(63.6 \%$ of the respondents were female). This represents $12.4 \%$ of one lecture through a survey method and was due to the voluntary nature of this 90-min component, which was to be completed during the students' free time within a limited time frame.

Since the subsample of 55 participants was embedded in the full lecture sample, it was possible to test for selection effects. Independent $t$ tests revealed that the two samples did not differ (see Table 1) in terms of the demographic variables and individual characteristics examined (for all $t$ tests: $p=\geq .05 ; d=0.03-0.18$ ). The subsample was comparable to the full sample. Students in the subsample were about 21 years old $(M=20.67, S D=2.10)$ and were in the second or third semester of their university program $(M=2.70, S D=2.78)$.

Table 1 Descriptive statistics of dependent and independent variables: full sample and subsample

\begin{tabular}{|c|c|c|c|c|}
\hline \multirow[b]{2}{*}{ Variable } & \multicolumn{2}{|c|}{$\begin{array}{l}\text { Full sample } \\
N=443\end{array}$} & \multicolumn{2}{|c|}{ Subsample $N=55$} \\
\hline & $M$ & $S D$ & $M$ & $S D$ \\
\hline \multicolumn{5}{|l|}{ Professional vision } \\
\hline Knowledge-based reasoning (total score) & & & $.36^{*}(-0.69)$ & $.16^{*}(0.10)$ \\
\hline Description & & & $.40^{*}(-0.37)$ & $.16^{*}(0.84)$ \\
\hline Explanation & & & $.34^{*}(-0.73)$ & $.18^{*}(1.04)$ \\
\hline Prediction & & & $.33^{*}(-0.93)$ & $.22^{*}(1.25)$ \\
\hline \multicolumn{5}{|l|}{ Educational background } \\
\hline High school GPA & 2.22 & 0.51 & 2.15 & 0.47 \\
\hline Number of generic pedagogical courses in teaching/learning & & & 4.27 & 3.27 \\
\hline Length of internships at school ${ }^{\mathrm{a}}$ & 2.17 & 4.39 & 1.94 & 3.01 \\
\hline \multicolumn{5}{|l|}{ Interest } \\
\hline Interest in teaching profession & 3.49 & 0.46 & 3.57 & 0.38 \\
\hline Interest study generic pedagogical contents & 2.76 & 0.59 & 2.92 & 0.50 \\
\hline Interest in the generic pedagogical content area teaching/learning & 3.60 & 0.54 & 3.64 & 0.54 \\
\hline
\end{tabular}

Data were not available on all scales for the full sample. Interest in teaching profession and interest to study generic pedagogical contents scale from 1 (disagree) to 4 (agree); interest in the generic pedagogical content area teaching/learning scale from 0 (very low) to 5 (very high). * Fraction of correct answers; values in parentheses are weighted likelihood estimator (WLE) parameters

${ }^{\mathrm{a}}$ In weeks 


\section{Materials}

The Observer Tool We used the online Observer tool to assess participants' professional vision (Seidel et al. 2010). This tool is the first standardized instrument assessing the structure of professional vision (description, explanation, prediction) supposed by qualitative research (Seidel, and Stürmer 2014). It combines video clips recorded from real classroom situations with rating items, as illustrated in Fig. 1. In the instrument, participants are shown six 2- to 4-min video clips, which function as item prompts. The clips show instruction in different subjects at the secondary level. Each clip represents two of the core components of effective teaching and learning (i.e., goal clarity, teacher support, or learning climate). The clips are embedded in rating formats that refer to the respective instructional components.

The participants' ability to describe, explain, and predict relevant classroom interactions and outcomes were measured with six items per ability (18 items in total per component; 36 items in total per clip). Sample items are presented in Table 2. All responses were given on a 4-point Likert scale (1=disagree to 4=agree). The students' responses were compared with a criterion norm using expert judgments $(0=$ miss expert rating and $1=$ hit expert rating). This approach is based on the assumption that experts are characterized by having acquired well-structured and integrated knowledge that they use while accomplishing a professional task, such as reasoning about video clips (Ericsson et al. 1993). The expert norm was established by independent ratings of the Observer items of three teaching and learning researchers who all had 100-400 h of

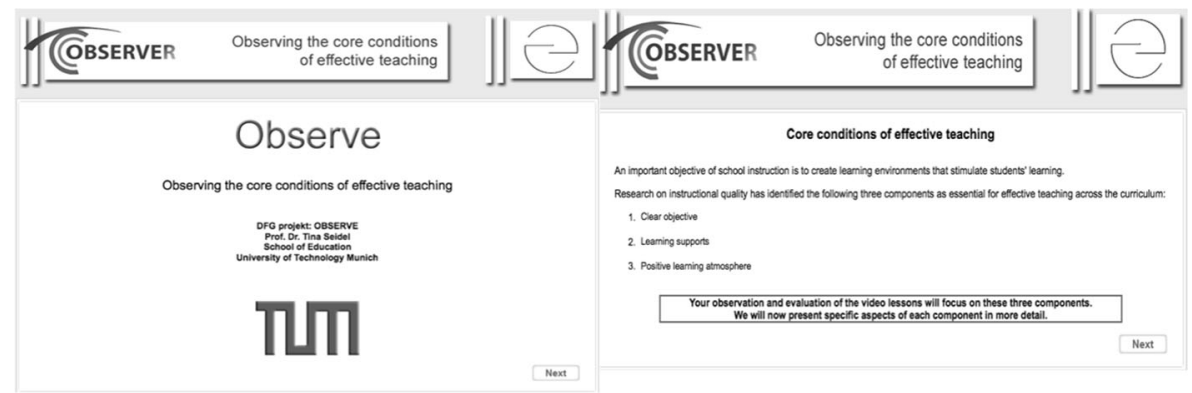

a) Front page

b) Short introduction of TL components

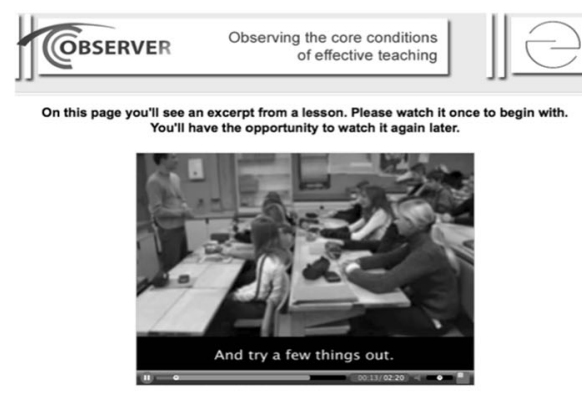

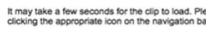

c) Presentation of video clips

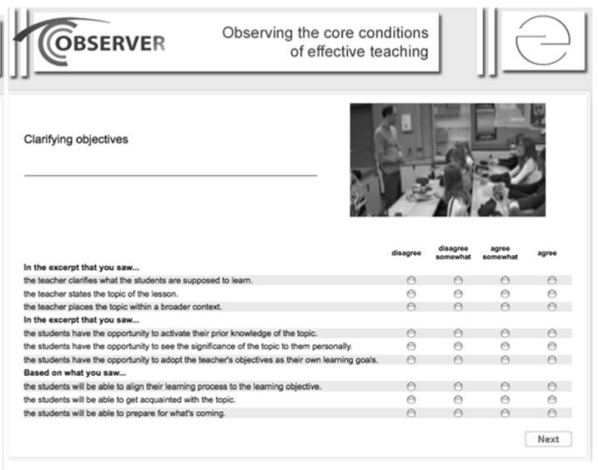

d) Followed by standardized rating items targeting reasoning

Fig. 1 The Observer Tool (Seidel and Stürmer, 2014) 
Table 2 Examples of rating items that tap into reasoning (see Seidel, and Stürmer 2014)

Aspects of knowledge-based reasoning Rating items

Goal clarity: Clarifying the learning goals

Description

In the excerpt that you saw... the teacher clarifies what the students are supposed to learn.

the teacher states the topic of the lesson.

the teacher places the topic within a broader context.

Explanation

In the excerpt that you saw...

the students have the opportunity to activate their prior knowledge of the topic.

the students have the opportunity to see the significance of the topic to them personally.

the students have the opportunity to adopt the teacher's objectives as their own learning goals.

Prediction

Based on what you saw...

the students will be able to align their learning process to the learning objective.

the students will be able to get acquainted with the topic.

the students will be able to prepare for what's coming.

Learning climate: Teacher takes students' needs seriously

Description

In the excerpt that you saw... the teacher is respectful of the students.

the teacher shows that he values the students.the teacher asks questions/sets tasks that are appropriate for the students' level of development.

Explanation

In the excerpt that you saw...

the students have the opportunity to feel that their teacher takes them seriously.

the students have the opportunity to contribute substantively in discussions with their teacher.

the students have the opportunity to develop their own ideas about the material covered.

Prediction

Based on what you saw... the teaching style will motivate the students.

the students will be mentally engaged.

the students will be able to feel at ease in the lesson.

experience in observing and interpreting classroom situations in generic pedagogical contents. Cohen's kappa ( $\mathrm{K}$ ) was calculated to determinate the consistency of the expert ratings; a mean Cohen's $k$ of .79 across the three raters indicated a satisfactory level of consistency. In cases where the experts disagreed, agreement was reached by consensus validation (Seidel and Stürmer 2014).

Analyses of the psychometric properties of the instrument based on item response theory have confirmed that the Observer tool provides a valid and reliable assessment of professional vision (Jahn et al. 2014; Seidel and Stürmer 2014). In two scaling 
studies of more than 1,000 preservice teachers, different measures and models that describe the structure of professional vision were applied, and fit indices were compared. The results provide about the reliability with regard to an overall scale of professional vision $(\alpha=.97)$ as well as description $(\alpha=.76)$, explanation $(\alpha=.73)$, and prediction $(\alpha=.90)$. Furthermore, two studies investigating preservice teachers' changes over time indicated that the Observer instrument is sensitive to capturing developments of professional vision within university-based teacher education (Stürmer et al. 2012, 2013), while at the same time working with the tool does not lead to an increase (Seidel, and Stürmer 2014).

Individual Characteristics First, the participants' school ability was measured by their high school GPA (German range: $6=$ minimum to $1=$ maximum). Second, we investigated their interest in the generic pedagogical part of their program. We distinguished various aspects of interest. First, preservice teachers' motivation to become teachers reflects their general interest in teaching as a profession (Pohlmann and Möller 2010). This was assessed with a scale containing six items $(\alpha=.85$; e.g., "I chose to study teaching because I like working with children and young people"). Items were rated on a 4-point scale (1=disagree to $4=$ agree $)$. A second aspect described the participants' interest in studying generic pedagogical contents. The extent to which preservice teachers were interested in the generic pedagogical part of their teacher education program was assessed with the Study Interest Questionnaire developed by Schiefele et al. (1993). Responses to the scale's 18 items (e.g., "I chose to study pedagogy primarily because the subject interests me") were given on the same 4-point scale $(\alpha=.94)$. A third aspect concerns preservice teachers' interest in the generic pedagogical content area of teaching and learning. The scale assessed participants' interest (Drechsel 2001) on a 6-point scale $(0=$ very low to $5=$ very high; $\alpha=.91)$. The following is a sample item: "If you think on the topic learning: How much you would like to learn more about how learning is influenced by various teaching factors."

Opportunities to Learn (OTL) Regarding learning opportunities, we assessed the number of preservice teachers' formal and informal OTL that they had used thus far. In addition to the introductory course the study was embedded in, preservice teachers had the opportunity to take more in-depth courses on teaching and learning on a voluntary basis at an early point in their training. These in-depth courses covered topics such as learning theories, self-regulation of learning, learning motivation, meta-cognition, and effective components of instruction. We assessed how many one-semester generic pedagogical courses in teaching and learning the participants had taken. Furthermore, we assessed preservice teachers' informal OTL in the form of the length of practical internships at school (in weeks).

\section{Procedure}

In the first session of the 2008-2009 winter semester, all preservice teachers enrolled in the introductory lecture were asked to complete a 45-min questionnaire on their individual characteristics and the number of OTL. Additionally, they were invited to participate in the Observer tool. The professor gave the students a brief description of the content and objectives of the Observer as well as the link to the website hosting the 
instrument. Participants had the two following sessions to voluntarily fill out the online assessment before the course contents of the Observer tool about effective teaching and learning components were introduced. After 1 week, they received a reminder via email.

\section{Data Analysis}

We followed the requirements of item response theory (IRT) and used a Rasch model as a standard in educational test construction (i.e., Co-operation \& Development, 2005). We estimated person parameters (measurement of abilities) using weighted likelihood estimators (WLEs) for preservice teachers' knowledge-based reasoning (Wu et al. 1997) and description, explanation, and prediction subscales. Taking item difficulty into account, the WLE parameters describe preservice teachers' knowledge-based reasoning ability on a logit scale with an average person ability of 0 . Scores on the logit scales ranged from -5 to 3 .

To answer the research question, we calculated bivariate Pearson's correlations between preservice teachers' WLE parameters and individual characteristics and performed multiple regression analyses in a backward procedure, with individual characteristics as independent variables and the WLE parameters as dependent variables, taking into account the interrelation between independent variables. Because of the suspected differences in the three subdimensions of knowledge-based reasoning, we conducted separate multiple regression analyses for describing, explaining, and predicting. The number of semesters was included as a control variable because possible differences in performance may depend on the phase in professional development.

\section{Results}

To investigate which individual characteristics and OTL were systematically related to preservice teachers' initial knowledge-based reasoning ability, Table 3 presents the bivariate correlations of all dependent and independent variables. The results showed that knowledge-based reasoning was positively related to the number of attended generic pedagogical courses in teaching and learning $(r=.36, p=.01)$ and the interest in the generic pedagogical content area teaching and learning $(r=.37, p=.01)$. In particular, these factors were related to the preservice teachers' scores on the explanation (generic pedagogical courses in teaching and learning: $r=.37, p=.01$; interest in the generic pedagogical content area teaching and learning: $r=.47, p=<.01$ ) and prediction (generic pedagogical courses in teaching and learning: $r=.36, p=.01$; interest in the generic pedagogical content area teaching and learning: $r=.30, p=.03$ ) subscales. Prior practical experience in school and high school GPA were not associated with knowledge-based reasoning.

Table 4 presents the results of the multiple regression analyses for the overall score of the preservice teachers' knowledge-based reasoning ability as well as the subdimensions (description, explanation, prediction). The independent variables included in the analyses were high school GPA, number of generic pedagogical courses in teaching and learning, length of internship in school (in weeks), interest in teaching 
Table 3 Pearson's intercorrelations between independent variables and professional vision

\begin{tabular}{|c|c|c|c|c|c|c|c|c|c|c|c|}
\hline Variables & & $\mathrm{a}$ & $\mathrm{b}$ & $\mathrm{c}$ & $\mathrm{d}$ & 1 & 2 & 3 & 4 & 5 & 6 \\
\hline $\mathrm{a}$ & Knowledge-based reasoning total $_{1}$ & - & & & & & & & & & \\
\hline $\mathrm{b}$ & Description & $.88^{* *}$ & - & & & & & & & & \\
\hline $\mathrm{c}$ & Explanation & $.91^{* *}$ & $.72^{* *}$ & - & & & & & & & \\
\hline d & Prediction & $.94^{* *}$ & $.74^{* * *}$ & $.79^{* *}$ & - & & & & & & \\
\hline 1 & High school GPA & .01 & -.01 & -.05 & .08 & - & & & & & \\
\hline 2 & $\begin{array}{l}\text { Number of generic pedagogical } \\
\text { courses in teaching/learning }\end{array}$ & $.36^{* *}$ & .24 & $.37^{* *}$ & $.36^{* *}$ & .10 & - & & & & \\
\hline 3 & Length of internships in school ${ }^{\mathrm{a}}$ & $<.01$ & .02 & -.04 & .02 & .12 & .04 & - & & & \\
\hline 4 & Interest in teaching profession & .16 & .11 & .21 & .15 & -.12 & .17 & .10 & - & & \\
\hline 5 & $\begin{array}{l}\text { Interest study generic pedagogical } \\
\text { contents }\end{array}$ & .17 & .09 & .20 & .18 & -.24 & -.05 & .15 & $.57^{* *}$ & - & \\
\hline 6 & $\begin{array}{l}\text { Interest in the generic pedagogical } \\
\text { content area teaching/learning }\end{array}$ & $.37^{* *}$ & .24 & $.47^{* *}$ & $.30^{* *}$ & -.23 & .10 & .09 & .26 & $.36^{* *}$ & - \\
\hline
\end{tabular}

${ }^{\mathrm{a}}$ In weeks. ${ }^{*} p<0.05 ;{ }^{* *} p<0.01$ (two-tailed)

as a profession, interest in studying generic pedagogical contents, and interest in the generic pedagogical content area teaching and learning. Table 4 include only variables, which are significant at a level of $p<.01$. It was revealed that the knowledge-based reasoning total score was strongly related to sources specific for learning in the content area teaching and learning, including the number of generic pedagogical courses in teaching and learning and specific interest in the generic pedagogical content area teaching and learning as significant predictors. Together, these sources explained $24 \%$ of the variance in knowledge-based reasoning (interest in the generic pedagogical content area teaching and learning $14 \%$, number of generic pedagogical courses in teaching and learning $9 \%$ ).

Table 4 Significant regression weights $(p<.05)$ of variables predicting professional vision

\begin{tabular}{|c|c|c|c|c|c|c|}
\hline Dependent variable & $R^{2}$ & $\Delta R^{2}$ & Independent variable(s) & $B$ & $S E B$ & $\beta$ \\
\hline \multirow[t]{2}{*}{$\begin{array}{l}\text { Knowledge-based } \\
\text { reasoning total }\end{array}$} & .24 & .14 & $\begin{array}{l}\text { Interest in the generic pedagogical content } \\
\text { area teaching/learning }\end{array}$ & .60 & .24 & .32 \\
\hline & & .09 & $\begin{array}{l}\text { Number of generic pedagogical courses in } \\
\text { teaching/learning }\end{array}$ & .10 & .04 & .31 \\
\hline Description & .07 & & & & & \\
\hline \multirow[t]{2}{*}{ Explanation } & .33 & .23 & $\begin{array}{l}\text { Interest in the generic pedagogical content area } \\
\text { teaching/learning }\end{array}$ & .87 & .23 & .44 \\
\hline & & .09 & $\begin{array}{l}\text { Number of generic pedagogical courses in } \\
\text { teaching/learning }\end{array}$ & .10 & .04 & .29 \\
\hline Prediction & .17 & .11 & $\begin{array}{l}\text { Number of generic pedagogical courses in } \\
\text { teaching/learning }\end{array}$ & .17 & .05 & .42 \\
\hline
\end{tabular}

All multiple regression models are corrected for semester effects. $R^{2}$ is the total amount of explained variance of the model, including semester effects. $\Delta R^{2}$ is the change in $R^{2}$ after the particular independent variable was added in the model. If no independent variable significantly predicts a dependent variable, only $\mathrm{R}^{2}$ is reported 
The investigated individual characteristics and OTL did not explain the ability to describe classroom situations. On the subdimension "explanation," it was shown that the number of generic pedagogical courses in teaching and learning and the participants' interest in the generic pedagogical content area teaching and learning were significantly related to the ability to explain classroom situations. These two variables together explained $33 \%$ of the variance. Interest in the generic pedagogical content area teaching and learning explained $23 \%$ of the variance, and the number of generic pedagogical courses in teaching and learning $9 \%$. On "prediction," it was shown that the number of generic pedagogical courses in teaching and learning was related to the ability to predict consequences of critical classroom situations, explaining $17 \%$ of the variance.

\section{Discussion}

The aim of this study was to advance the scientific understanding of the factors that contribute to explaining preservice teachers' integrated knowledge acquisition. In previous research, individual characteristics and OTL were investigated with regard to how they contribute to explaining learning outcomes in university-based teacher education. However, researchers have recently defined acquiring conceptual knowledge as an academic outcome. We investigated which factors are related to preservice teachers' professional vision as an indicator of the initial integrated knowledge structures. We focused on the relation between preservice teachers' incipient professional vision and influencing factors at the beginning of their educational program to identify important opportunities for the development processes.

Our results show that preservice teachers' professional vision is systematically related to the number of attended generic pedagogical courses in teaching and learning and their interest in this content area. In particular, these two factors were positively associated with the subscales "explanation" and "prediction." Both factors were related to preservice teachers' ability to explain classroom situations regarding generic pedagogical knowledge of teaching and learning. The number of generic pedagogical courses in teaching and learning was also related to preservice teachers' ability to predict the consequences of observed events in terms of student learning. Since the ability to explain and predict the effects of observed classroom situations requires the application of higher-order knowledge structures (Kersting et al. 2010), these findings emphasize the importance of content-specific learning for developing expertise (Borko 2004; Ericsson et al. 1993). At the beginning of initial teacher education programs, preservice teachers' ability in knowledge-based reasoning was strongly related to the resources specific for learning in the content area teaching and learning (e.g., formal OTL in generic pedagogical knowledge and content-specific interest). Regarding effective university-based teacher education, the development of professional vision requires conditions of content-specific knowledge acquisition.

In studying preservice learning processes and improving curricular designs, the identification of factors that contribute to explaining outcomes is seen as necessary research (Fenollar et al. 2007; Ruban and McCoach 2005). Our results seem to confirm the explanatory value of important factors pointed out in earlier research: individual characteristics and OTL. However, we used a new approach, focusing on the 
acquisition of integrated knowledge structures as a more effective outcome of teacher education. In the last few years, professional vision has become an important element for describing initial knowledge acquisition for instructional action within universitybased teacher education (Star and Strickland 2008; Stürmer, et al. 2012, 2013; Wiens et al. 2013). With the Observer instrument, a reliable and valid measure is available for assessing the development of integrated knowledge structures within university-based teacher education. This constitutes an important requirement for discussing and improving the effectiveness of teacher education in generic pedagogical knowledge acquisition (Bauer and Prenzel 2012; Seidel 2012). Our results identify "interest" as an important individual source for developing integrated knowledge, while previous studies focused on conceptual knowledge acquisition pointed out the predictive value of high school GPA (i.e., Blömeke et al. 2008). Our results provide support for the assumption that, when it comes to the application of knowledge to practice, high school GPA has a poor predictive value (Ericsson et al. 1993; Hulin et al. 1990) and is a toodistal parameter (Burton and Ramist 2001).

Regarding formal and informal OTL, our results seem to confirm the general impact of university-based teacher education as a source of knowledge acquisition that constitutes a baseline for initial professional development processes (i.e., Grossman 1990). Professional vision is seen as a strongly knowledge-guided process (Palmeri et al. 2004). Assessed with the Observer tool, professional vision requires knowledge about effective teaching and learning components, such as knowledge about goal clarity and teacher support (Seidel, and Stürmer 2014). Attending more in-depth courses in teaching and learning seems to be an opportunity for the accumulation of knowledge, which preservice teachers could draw on by reasoning about classroom situations.

To support the transfer of theory to practice, internships are implemented in all university-based teacher education programs. The implementation is based on the assumption that practical experiences impact the development of well-defined knowledge structures. However, our results show that the amount of practical experience in schools does not explain the differences in preservice teachers' professional vision. Whereas within the formal OTL in university-based programs the learning content is summarized for effective instructional practice, in informal OTL students have several sources to learn from: the subject matter, the theory from the institute or school, their own experiences during teaching practice, and the practical knowledge of the cooperating teacher at the school (Vermunt and Endedijk 2011). Depending on the schools where students have gained experience, the professional discourse going on there, and the guidance they have received (in school and from the university), they may have developed different and, to some extent, subjective theories and concepts about teaching and learning (Putnam and Borko 2000). These may in turn facilitate or impede the integration of new knowledge in the context of initial teacher education programs.

Our study shows that learning sources in the content area teaching and learning, more specifically in the formal courses on generic pedagogical knowledge and contentspecific interest in teaching and learning, affects preservice teachers' initial professional vision. This demonstrates that expertise is not just a matter of learning by doing but also of learning on the informed basis of knowledge about and interest in the content area teaching and learning. On the one hand, expertise research shows that successful on-job performance goes along with continued reflected learning in the context of practice 
(Ericsson et al. 1993). On the other hand, it has been shown that teachers' expertise is informed by formal knowledge provided at universities (cf. Bauer, and Prenzel 2012). In this vein, our results confirm that professional development processes require a deliberate practice founded on evidence-based knowledge (Ericsson et al. 1993).

\section{Limitations}

Although, the current study shows that individual characteristics and formal OTL, which contribute to explaining conceptual knowledge acquisition, can also be identified regarding the integrated development of knowledge structures, some limitations must be taken into account. Considering the full sample, 55 preservice teachers participated in the Observer assessment. With regard to demographic variables and individual characteristics, such as interest in generic pedagogical contents, the students who worked with the tool do not differ from the full sample. However, previous research shows that voluntary participation is related to higher motivation in working with the tool (Jahn et al. 2011). Although, working motivation does not affect the performance in professional vision itself (Jahn et al. 2011), the reasons for and effects of voluntary participation require more extensive study. Furthermore, the sample size does not allow the application of parametric analysis methods, which could provide insights into mediating effects between the independent variables. With regard to the OTL, we note that the amount alone is a rather distal indicator. The in-depth courses covered topics such as learning theories, self-regulation of learning, learning motivation, meta-cognition, and effective components of instruction; however, it is unclear whether some courses had a stronger impact on knowledge acquisition than others. For example, video-based courses in which reasoning of observed teaching situations is trained support the development of preservice teachers' professional vision (Stürmer et al. 2012). Although, the curriculum in the teacher education program under investigation did not provide video-based courses in teaching and learning, we did not control for pre-experiences in working with videos. The same ambiguity holds for the quality of the practical teaching experiences preservice teachers have gathered so far. In terms of supporting preservice teachers in their development of on-job performance experience, a constant monitoring of course instruction and activities within formal and informal, university-based teacher education is necessary (Berk and Hiebert 2009).

Author Note The Observe project (SE 1397/2-2) is funded by the German Research Foundation as part of the priority research program, "Competence Models for Assessing Individual Learning Outcomes and Evaluating Educational Processes." We would like to thank the preservice teachers who participated in this study.

\section{References}

Bauer, J., \& Prenzel, M. (2012). European teacher training reforms. Science, 336(6089), 1642-1643. doi:10. 1126/science. 1218387.

Baumert, J., Kunter, M., Blum, W., Brunner, M., Voss, T., Jordan, A., \& Yi-Miau, T. (2010). Teachers' mathematical knowledge, cognitive activation in the classroom, and student Progress. American Educational Research Journal, 47(1), 133-180. 
Bennware, C., \& Deci, E. (1984). Quality of learning with an active versus passive motivational set. American Educational Research Journal, 21, 755-765.

Berk, D., \& Hiebert, J. (2009). Improving the mathematics preparation of elementary teachers, one lesson at time. Teachers and Teaching: Theory and Practice, 15(3), 337-356.

Berliner, D. C. (1991). Perceptions of student behavior as a function of expertise. Journal of Classroom Interaction, 26(1), 1-8.

Berliner, D. C. (2001). Learning about and learning from expert teachers. International Journal of Educational Research, 35, 463-482.

Berliner, D. C., Stein, P., Sabers, D. S., Clarridge, P. B., Cushing, K. S., \& Pinnegar, S. (1988). Imlication of research on pedagogical expertise and experience in mathematics teaching. In D. A. Grouws \& T. J. Cooney (Eds.), Perspectives on research on effective mathematics teaching (pp. 67-95). Reston, VA: National Council of Teachers of Mathematics.

Blomberg, G., Stürmer, K., \& Seidel, T. (2011). How pre-service teachers observe teaching on video: effects of viewers' teaching subjects and the subject of the video. Teaching and Teacher Education, 27, 1131-1140.

Blömeke, S., Felbrich, A., \& Müller, C. (2008). Erziehungswissenschaftliches wissen am ende der lehrerausbildung. [Peadogogical knowledge at the end of teacher education]. In S. Blömeke, G. Kaiser, \& R. Lehmann (Eds.), Professionelle kompetenzen angehender lehrerinnen und lehrer. Wissen, überzeugungen und lerngelegenheiten deutscher mathematik-studierender und -referendare - erste ergebnisse zur wirksamkeit (pp. 195-217). Münster: Waxman.

Blömeke, S., Suhl, U., Kaiser, G., \& Döhrmann, M. (2012). Family background, entry selectivity and opportunities to learn: What matters in primary teacher education? An international comparison of fifteen countries. Teacher and Teacher Education, 28, 44-55. doi:10.1016/j.tate.2011.08.006

Borko, H. (2004). Professional development and teacher learning: mapping the terrain. Educational Researcher, 33(8), 3-15. doi:10.3102/0013189x033008003.

Borko, H., \& Livingston, C. (1989). Cognition and improvisation: differences in mathematics instruction by expert and novice teachers. American Educational Research Journal, 26(4), 473-498. doi:10.3102/ 00028312026004473.

Borko, H., Jacobs, J. K., Eiteljorg, E., \& Pittman, M. E. (2008). Video as a tool for fostering productive discussions in mathematics professional development. Teaching and Teacher Education, 24(2), 417-436. doi:10.1016/j.tate.2006.11.012.

Brouwer, N. (2010). Determining long term effects of teacher education. In P. Peterson, E. Baker, \& B. McGaw (Eds.), International encyclopedia of education (pp. 503-510). Oxford: Elsevier.

Brouwer, N., \& Korthagen, F. (2005). Can teacher education make a difference? Paper presented at the American Educational Research Association.

Burton, N. W., \& Ramist, L. (2001). Predicting success in college: SAT studies of classes graduating since 1980.

Carter, K., Sabers, D., Cushing, K., Pinnegar, P., \& Berliner, D. C. (1987). Processing and using information about students: a study of expert, novice and postulant teachers. Teaching and Teacher Education, 3, 147-157.

Cochran-Smith, M. (2003). Assessing assessment in teacher education. Journal of Teacher Education, 54(3), 187-191.

Cochran-Smith, M., \& Fries, K. (2005). The AERA panel on research and teacher education: Context and goals. In M. Cochran-Smith \& K. M. Zeichner (Eds.), Studying teacher education (pp. 37-68). Mahwah, NJ: Lawrence Erlbaum Associates.

Cochran-Smith, M., \& Zeichner, K. M. (Eds.). (2005). Studying teacher education: The report of the AERA panel on research and teacher education. Mahwah, NJ: Lawrence Erlbaum Associates.

Co-operation, Organisation for Economic, \& Development. (2005). PISA 2003 technical report. Paris: OECD.

Darling-Hammond, L. (2006). Assessing teacher education: the usefulness of multiple measures for assessing program outcomes. Journal of Teacher Education, 57(2), 120-138. doi:10.1177/0022487105283796.

Darling-Hammond, L. (2010). Teacher education and the American future. Journal of Teacher Education, 61(1-2), 35-47. doi:10.1177/0022487109348024.

Darling-Hammond, L., \& Bransford, J. D. (Eds.). (2005). Preparing teachers for a changing world: What teachers should learn and be able to do. San Francisco: Jossey-Bass.

Dewey, J. (1913). Interest and effort in education. Boston: Riverside Press.

Drechsel, B. (2001). Subjektive Lernbegriffe und Interesse am Thema Lernen bei angehenden Lehrpersonen. [Future teachers subjective terms of learning and interest in the topic of learning]. Münster: Waxman.

Eccles, J. S. (1984). Sex differences in achievement patterns. In T. Sonderegger (Ed.), Nebraska symposium on motivation (pp. 97-132). Lincoln, NE: University of Nebraska Press.

Elliot, A. J., \& Murayama, K. (2008). On the measurement of achievement goals: critique, illustration, and application. Journal of Educational Psychology, 100, 613-628. 
Eraut, M. (2004). Informal learning in the workplace. Studies in Continuing Education, 26(2), 247-273. doi: $10.1080 / 158037042000225245$.

Ericsson, K. A., Krampe, R. T., \& Tesch-Römer, C. (1993). The role of deliberate practice in the acquisition of expert performance. Psychological Review, 100(3), 363-406.

Feiman-Nemser, S. (1990). Teacher preparation: Structural and conceptual alternatives. In W. Houston (Ed.), Handbook on research on teacher education (pp. 212-233). New York, NY: Macmillan.

Fenollar, P., Romàn, S., \& Cuestas, P. J. (2007). University students' academic performance: an integrative conceptual framework and empirical analysis. British Journal of Educational Psychology, 77, 873-981. doi:10.1348/000709907X189118.

Floden, R. E., \& Meiketti, M. (2005). Research on the effects of coursework in the arts and science an in the foundations of education. In M. Cochran-Smith \& K. Zeichner (Eds.), Studying teacher education. Mahwah: Lawrence Erlbaum.

Fraser, B. J., Walberg, H. J., Welch, W. W., \& Hattie, J. A. (1987). Syntheses of educational productivity research. International Journal of Educational Research, 11, 145-252.

Goodwin, C. (1994). Professional vision. American Anthropologist, 96(3), 606-633. doi:10.1525/aa.1994.96. $3.02 \mathrm{a} 00100$.

Gröschner, A., Schmitt, C., \& Seidel, T. (2013). Veränderung subjektiver Kompetenzeinschätzungen von Lehramtsstudierenden im Praxissemester. [Changes in preservice teachers subjective estimation on competencies during a school internship]. Zeitschrift für Pädagogische Psychologie, 27 (1). doi:10. 1024/1010-0652/a000090

Grossman, P. (1990). The making of a teacher. Teacher knowledge and teacher education. New York: Teachers College Press.

Grossman, P., \& McDonald, M. (2008). Back to the future: directions for research in teaching and teacher education. American Educational Research Journal, 45(1), 184-205. doi:10.3102/0002831207312906.

Grossman, P., Compton, C., Igra, D., Ronfeldt, M., Shahan, E., \& Williamson, P. W. (2009). Teaching practice: a cross-professional perspective. Teachers College Record, 111(9), 2055-2100.

Hammerness, K., Darling-Hammond, L., \& Shulman, L. S. (2002). Toward expert thinking: how curriculum case writing prompts the development of theory-based professional knowledge in student teachers. Teaching Education, 13(2), 219-243.

Harackiewicz, J. M., Durik, A. M., Barron, B., Linnenbrink-Garcia, L., \& Trauer, J. M. (2008). The role of achievement goals in the development of interest: reciprocal relations between achievement goals, interest, and performance. Journal of Educational Psychology, 100, 105-122.

Hattie, J. (2009). Visible learning: A synthesis of over 800 meta-analysis relating to achievment. New York: Routledge.

Hidi, S., \& Harackiewicz, J. M. (2000). Motivating the academically unmotivated: a critical issue for the 21 st century. Review of Educational Research, 70, 151-179.

Hidi, S., \& Renninger, K. A. (2006). The four phase model of interest development. Educational Psychologist, $41,111-127$.

Hill, H. C., Rowan, B., \& Ball, D. L. (2005). Effects of teachers' mathematical knowledge for teaching on student achievement. American Educational Research Journal, 42(2), 371-406. doi:10.3102/ 00028312042002371.

Hulin, C. L., Henry, R. A., \& Noons, S. L. (1990). Adding a dimension: time as a factor in the generalizability of predictive relationships. Psychological Bulletin, 107, 328-340.

Jahn, G., Prenzel, M., Stürmer, K., \& Seidel, T. (2011). Varianten einer computergestützten Erhebung von Lehrerkompetenzen. [Variation in computer-based assessments of teacher competencies. Unterrichtswissenschaft, 39(2), 136-153.

Jahn, G., Stürmer, K., Seidel, T., \& Prenzel, M. (2014). Professionelle Unterrichtswahrnehmung von Lehramtsstudierenden. Eine Scaling-up Studie des Observe-Projekts [Preservice teachers' professional sision. A Scaling-up of the Observe project]. Zeitschrift für Entwicklungspsychologie und Padagogische Psychologie.

Kennedy, A. M., Ahn, S., \& Choi, J. (2008). The value added by teacher education. In M. Cochran-Smith, S. Feiman-Nemser, D. J. McIntyre, \& K. E. Demers (Eds.), Handbook of research on teacher education: Vol. 3 (pp. 1249-1273). New York, NY: Routledge.

Kersting, N., Givvin, K. B., Sotelo, F. L., \& Stigler, J. W. (2010). Teachers' analyses of classroom video predict student learning of mathematics: further explorations of a novel measure of teacher knowledge. Journal of Teacher Education, 61(1-2), 172-181. doi:10.1177/0022487109347875.

Kleickmann, T., Richter, D., Kunter, M., Elsner, J., Besser, M., Krauss, S., \& Baumert, J. (2012). Teachers' content knowledge and pedagogical content knowledge: The role of structural differences in teacher education. Journal of Teacher Education, 1-17. doi:10.1177/0022487112460398 
Kunina-Habenicht, O., Schulze-Stocker, F., Kunter, M., Baumert, J., Leutner, D., Förster, D., \& Terhart, E. (2013). Die Bedeutung der Lerngelegenheiten im Lehramtsstudium und deren individuelle Nutzung für den Aufbau des bildungswissenschaftlichen Wissens. [The meaning of opportunities to learn within university-based teacher education for the development of generic peadagogical knowledge]. Zeitschrift für Pädagogik, 59(1), 1-23.

Loewenberg Ball, D., \& Cohen, D. K. (1999). Developing practice, developing practitioners - Toward a practice-based theory of professional education. In G. Sykes \& L. Darling-Hammond (Eds.), Teaching as the learning profession: Handbook of policy and practice. San Francisco: Jossey-Bass.

Lortie, D. (1975). School teacher: A socialogical study. Chicago: University of Chicago Press.

Munby, H., Russell, T., \& Martin, A. K. (2001). Teachers' knowledge and how it develops. In V. Richardson (Ed.), Handbook of research on teaching (pp. 877-904). Washington, D.C: American Educational Research Association.

Musso, M. F., Kyndt, E., Cascallar, E. C., \& Dochy, F. (2013). Predicting general academic performance and identifying the differential contribution of participating variables using artificial neural networks. Frontline Learning Research, 1, 42-71.

Noell, G. H., \& Burns, J. L. (2006). Value-added assessment of teacher preparation - An illustration of emerging technology. Journal of Teacher Education, 57(1), 37-50. doi:10.1177/0022487105284466.

OECD. (2005). Attracting, developing and retaining effective teachers - Final report: Teachers matter. Paris: OECD.

Palmeri, T. J., Wong, A. C. N., \& Gauthier, I. (2004). Computational approaches to the development of perceptual expertise. Trends in Cognitive Sciences, 8(8), 378-386. doi:10.1016/j.tics.2004.06.001.

Pohlmann, B., \& Möller, J. (2010). Motivation für die Wahl des Lehramtsstudiums. Entwicklung eines Fragebogens zur Erfassung der Motivation für die Wahl des Lehramtstudiums (FEMOLA). [Motivation for choosing teacher profession. Development of an instrument]. Zeitschrift für Pädagogische Psychologie, 24, 73-84. doi:10.1024/1010-0652.a000005.

Putnam, R. T., \& Borko, H. (2000). What do new views of knowledge and thinking have to say about research on teacher learning? Educational Researcher, 29(1), 4-15.

Richardson, M., Bond, R., \& Abraham, C. (2012). Psychological correlates of university students' academic performance: A systematic review and meta-analysis. Psychological Bulletin, 138(2), 353-387. doi:10. 1037/a0026838.

Robbins, S. B., Lauver, K., Davis, D., Lanley, R., \& Carlstrom, A. (2004). Do psychosocial and study skill factors predict college outcome? A meta-analysis. Psychological Bulletin, 130, 261-288. doi:10.1037/ 0033-2909.130.2.261.

Ruban, L. M., \& McCoach, D. B. (2005). Gender differences in explaining grades using structural equation modelling. Review of Higher Education, 28, 475-502.

Sansone, C., \& Thoman, D. B. (2005). Interest as the missing motivator in self-regulation. European Psychologist, 10, 175-186.

Santagata, R., \& Guarino, J. (2010). Using video to teach future teachers to learn from teaching. ZDM The International Journal on Mathematics Education. doi:10.1007/s11858-010-0292-3.

Schiefele, H., Krapp, A., Wild, K. P., \& Winteler, A. (1993). Der "Fragebogen zum Studieninteresse" (FSI). [The questionnaire assessing study interest]. Diagnostica, 4, 335-351.

Schön, D. A. (1987). Educating the reflective practitioner. San Francisco, CA: Jossey-Bass.

Seidel, T. (2012). Implementing competence assessment in university education. Empirical Research in Vocational Education and Training, 4(1), 91-94.

Seidel, T., \& Prenzel, M. (2007). Wie Lehrpersonen Unterricht wahrnehmen und einschätzen - Erfassung pädagogisch-psychologischer Kompetenzen bei Lehrpersonen mit Hilfe von Videosequenzen. [How teachers observe and interpret classroom situations]. Zeitschrift für Erziehungswissenschaft, Sonderheft, 8, 201-218.

Seidel, T., \& Shavelson, R. J. (2007). Teaching effectiveness research in the past decade: the role of theory and research design in disentangling meta-analysis results. Review of Educational Research, 77(4), 454-499. doi:10.3102/0034654307310317.

Seidel, T., \& Stürmer, K. (2014). Modeling and measuring the structure of professional vision in pre-service teachers. American Educational Research Journal, 51(4), 739-771. doi:10.3102/0002831214531321.

Seidel, T., Stürmer, K., \& Blomberg, G. (Producer). (2010). Observer: Video-based tool to diagnose teachers' professional vision.

Seidel, T., Blomberg, G., \& Renkel, A. (2013). Instructional strategies for using video in teacher education. Teaching and Teacher Education, 34, 56-65. doi:10.1016/j.tate.2013.03.004.

Sherin, M. G. (2001). Developing a professional vision of classroom events. In T. Wood, B. S. Nelson, \& J. Warfield (Eds.), Beyond classical pedagogy: Teaching elementary school mathematics. Mahwah, NJ: Lawrence Earlbaum. 
Sherin, M. G. (2002). When teaching becomes learning. Cognition and Instruction, 20(2), 119-150. doi:10. 1207/S1532690XCI2002_1.

Sherin, M. G. (2007). The development of teachers' professional vision in video clubs. In R. Goldman, R. Pea, B. Barron, \& S. J. Derry (Eds.), Video research in the learning sciences (pp. 383-395). Mahwah, N.J: Lawrence Erlbaum.

Sherin, M. G., \& van Es, E. (2009). Effects of video club participation on teachers' professional vision. Journal of Teacher Education, 60, 20-37. doi:10.1177/0022487108328155.

Sherin, M. G., Jacobs, V. R., \& Philipp, R. A. (Eds.). (2011). Mathematics teacher noticing: Seeing through teachers' eyes. New York: Routledge.

Shulman, L. S. (1987). Knowledge and teaching: foundations of the new reform. Harvard Educational Review, 57(1), 1-22.

Singh, K., Granville, M., \& Dika, S. (2002). Mathematics and science achievement: effects of motivation, interest, and academic engagement. Journal of Educational Research, 95(6), 323-332.

Star, J. R., \& Strickland, S. K. (2008). Learning to observe: using video to improve preservice mathematics teachers' ability to notice. Journal of Mathematics Teacher Education, 11(2), 107-125. doi:10.1007/ s10857-007-9063-7.

Sternberg, R. J., \& Grigorenko, E. L. (2003). The psychology of abilities, competencies, and expertise. New York: Cambridge University Press.

Strenze, T. (2007). Intelligence and socioeconomic sucess: a meta-analytic review of longitudinal research. Intelligence, 35, 401-426. doi:10.1016/j.intell.2006.09.004.

Stürmer, K., Könings, K. D., \& Seidel, T. (2012). Declarative knowledge and professional vision in teacher education: effect of courses in teaching and learning. British Journal of Educational Psychology, 83, 467483. doi:10.1111/j.2044-8279.2012.02075.x.

Stürmer, K., Seidel, T., \& Schäfer, S. (2013). Changes in professional vision in the context of practice. Preservice teachers' professional vision changes following practical experience: a video-based approach in university-based teacher education. Gruppendynamik und Organisationsberatung, 44, 339-355. doi: 10.1007/s11612-013-0216-0.

Tynjälä, P. (2008). Perspective into learning at the workplace. Educational Research Review, 3, 130-154. doi: 10.1016/j.edurev.2007.12.001.

van Es, E., \& Sherin, M. G. (2002). Learning to notice: scaffolding new teachers' interpretations of classroom interactions. Journal of Technology and Teacher Education, 10(4), 571-596.

van Es, E., \& Sherin, M. G. (2008). Mathematics teachers' "learning to notice" in the context of a video club. Teaching and Teacher Education, 24(2), 244-276. doi:10.1016/j.tate.2006.11.005.

Vermunt, J. D., \& Endedijk, M. D. (2011). Patterns in teacher learning in different phases of the professional career. Learning and Individual Differences, 21(3), 294-302. doi:10.1016/j.lindif.2010.11.019.

Voss, T., Kunter, M., \& Baumert, J. (2011). Assessing teacher candidates' general pedagogical and psychological knowledge: test construction and validation. Journal of Educational Psychology, 103(4), 952-969. doi: $10.1037 / \mathrm{a} 0025125$.

Wayne, A. J., \& Youngs, P. (2003). Teacher characteristics and student achievement gains: a review. Review of Educational Research, 73(1), 89-122. doi:10.3102/00346543073001089.

Wiens, P. D., Hessberg, K., LoCasale, J., \& DeCoster, J. (2013). Using standarized video-based assessment in a university teacher education program to examine preservice teachers knowledge related to effective teaching. Teacher and Teacher Education, 33, 24-33. doi:10.1016/j.tate.2013.01.010.

Wigfield, A., \& Cambria, J. (2010). Students' achievement values, goal orientations, and interst: definitions, development, and relations to achievement outcomes. Develoment Review, 30, 1-35. doi:10.1016/j.dr. 2009.12.001.

Willingham, W. W., Lewis, C., Morgan, R., \& Ramist, L. (1990). Predicting college grades: an analysis of institutional trends over two decades. Princeton: Educational Testing Service.

Wu, M. L., Adams, R. J., \& Wilson, M. R. (1997). ConQuest: Multi-aspect test software. Camberwell: Australian Council for Education Research.

Wubbels, T., Brekelmans, M., \& Hooymayers, H. P. (1992). Do teacher ideals distort the self-reports of their interpersonal behavior. Teaching and Teacher Education, 8(1), 47-58. 